Recepción: 01 / 03/ 2018

Aceptación: 15 / 05 / 2018

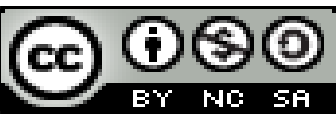

Ciencias Sociales

Publicación: 07 / 07 / 2018

\title{
The case of China's Economic Reform: The Xi Jinping Era, a comparative analysis with Mao Zedong and Deng Xiaoping
}

\section{El caso de la reforma económica de China: La Xi Jinping, un análisis comparativo con Mao Zedong y Deng Xiaoping}

\section{O caso da reforma econômica da China: a era Xi Jinping, uma análise comparativa com Mao Zedong e Deng Xiaoping}

\author{
Gema I. Sornoza-Parrales ${ }^{\text {I }}$ \\ gema@sornoza.com
}

Gema M. Conforme-Cedeno II gemicon87@hotmail.com

Viviana del Rocío Saltos-Buri III bibi_buri@hotmail.com

\author{
Laura C. Merchán-Nieto IV \\ laura.merchan@unesum.edu.ec
}

\author{
Laura P. Muñíz-Jaime ${ }^{\mathrm{V}}$ \\ laura.muniz@unesum.edu.ec
}

José A. Franco-Yoza vi

jose.franco@unesum.edu.ec

Correspondencia: gema@ sornoza.com

I. Maestrante de Administración Pública, Ingeniera en Comercio y Finanzas Internacionales Bilingüe. Renmin University of China, Haidian, China.

II. Magíster en Contabilidad y Auditoría, Ingeniera Comercial. Docente del Área de Emprendimiento, Universidad Estatal del Sur de Manabí. Jipijapa, Manabí, Ecuador.

III. Magíster en Contabilidad y Auditoría, Ingeniera en Administración de Empresas Agropecuarias. Docente de la Facultad de Ciencias Económicas, Carrera de Administración de Empresas, Universidad Estatal del Sur de Manabí. Jipijapa, Manabí, Ecuador.

IV. Magíster Internacional en Gestión de Instituciones de Salud, Economista. Docente de la Facultad de Ciencias Naturales y de la Agricultura, Carrera de Ingeniería Ambiental, Universidad Estatal del Sur de Manabí. Jipijapa, Manabí, Ecuador.

V. Magíster en Contabilidad y Auditoría, Economista. Docente de la Facultad de Ciencias Económicas, Carrera de Administración de Empresas, Universidad Estatal del Sur de Manabí. Jipijapa, Manabí, Ecuador.

VI. Magíster en Contabilidad y Auditoría, Economista. Docente de la Facultad de Ciencias Económicas, Carrera de Administración de Empresas, Universidad Estatal del Sur de Manabí. Jipijapa, Manabí, Ecuador. 


\section{Abstract}

China is a faithful example when things are done well, great results are obtained, in part thanks to the role that the same culture played in the growth it has had and still has. Work and savings have been fundamental pillars for the economic development that this country during the last decades, not leaving aside the role played by the Western economies to nurture this reality; first, with the policies implemented by Mao and Deng when the country was in a great crisis generating the necessary investment and establishing a sufficient number of factories that allow to reactivate the Chinese economy; secondly, the opening by Xi to the western region becoming the passage of time, in one of the largest consumers and at the same time the largest producers in the world in different areas.

In a certain sense, it seems as if the powers of the West have exceeded looking for more short-term benefit, but without realizing the consequences that could be faced by adopting these decisions. On the other hand, China knew how to play the cards, your business became a truly business profitable: lend money and then be reimbursed in the coffers of the country, for the concept of selling products and paying interest on loans. The work of the State in the planning of economic policies, to medium and long term, which led to the generation of a market economy socialist with Chinese characteristics, does not remain outside when defining the economic success of the Asian giant. The implementation of this new economic model, which knew how to combine some dynamics of capitalism within the communist system, it played a very important role. The fact of generating great coordination between the public and private sectors, in addition to capture the market signals in a timely manner, allowed the results and economic policies were heading towards a prosperous path.

Nor can we ignore the autonomy and independence that has had the Communist Party to make political and economic decisions with the greatest opportunism and speed possible. This is proper to have a power not shared, which has undoubtedly generated that the measures taken obtain a high degree of efficiency.

This is how the application in China of a series of dynamics is explained of capitalism that allowed it, in a succession of conditions presented, that would grow by leaps and bounds as opposed to economies of most of the industrialized countries of the West. It is also in this way that it is understood that China has been able to take from poverty to 800 million people in 30 years (World Bank, 2012) and that, currently, is in the longed for place to be the largest economy world.

Key words: China, Communist Party, Development, Country, Economy, Socialism, Political reform. 
Gema I. Sornoza-Parrales; Gema M. Conforme-Cedeno; Viviana del Rocío Saltos-Buri; Laura C. Merchán-Nieto; Laura P. Muñíz-Jaime; José A. Franco-Yoza

\section{Resumen}

China es un fiel ejemplo cuando las cosas se hacen bien, se obtienen excelentes resultados, en parte gracias al papel que jugó la misma cultura en el crecimiento que ha tenido y que todavía tiene. El trabajo y el ahorro han sido pilares fundamentales para el desarrollo económico de este país durante las últimas décadas, sin dejar de lado el papel desempeñado por las economías occidentales para nutrir esta realidad; primero, con las políticas implementadas por Mao y Deng cuando el país estaba en una gran crisis generando la inversión necesaria y estableciendo un número suficiente de fábricas que permitieran reactivar la economía china; en segundo lugar, la apertura de Xi a la región occidental se convirtió en el paso del tiempo, en uno de los mayores consumidores y al mismo tiempo los mayores productores en el mundo en diferentes áreas.

En cierto sentido, parece como si los poderes de Occidente hubieran excedido la búsqueda de más beneficios a corto plazo, pero sin darse cuenta de las consecuencias que se podrían enfrentar al adoptar estas decisiones. Por otro lado, China sabía cómo jugar las cartas, su negocio se convirtió en un verdadero negocio rentable: prestar dinero y luego ser reembolsado en los cofres del país, por el concepto de vender productos y pagar intereses sobre préstamos. El trabajo del Estado en la planificación de las políticas económicas, a mediano y largo plazo, que condujo a la generación de una economía de mercado socialista con características chinas, no queda fuera cuando se define el éxito económico del gigante asiático. La implementación de este nuevo modelo económico, que sabía cómo combinar algunas dinámicas del capitalismo dentro del sistema comunista, jugó un papel muy importante. El hecho de generar una gran coordinación entre los sectores público y privado, además de capturar las señales del mercado de manera oportuna, permitió los resultados y las políticas económicas se encaminaron hacia un camino próspero.

Tampoco podemos ignorar la autonomía e independencia que ha tenido el Partido Comunista para tomar decisiones políticas y económicas con el mayor oportunismo y velocidad posibles. Esto es propio de tener un poder no compartido, lo que indudablemente ha generado que las medidas tomadas obtengan un alto grado de eficiencia.

Así se explica la aplicación en China de una serie de dinámicas del capitalismo que le permitieron, en una sucesión de condiciones presentadas, crecer a pasos agigantados frente a las economías de la mayoría de los países industrializados de Occidente. También es de esta manera que se entiende que China ha podido llevar de la pobreza a 800 millones de personas en 30 años (Banco Mundial, 2012) y que, actualmente, se encuentra en el ansiado lugar para ser el mundo económico más grande.

Key words: Guanxi, relación social, pueblo chino. 


\section{Introducción.}

China is today the second world economic power, only surpassed by the United States, which watches with attention how every day the influence of the Asian giant increases, under the direction of the Communist Party, founded 95 years ago.

The future that today builds that great nation began to take shape from its foundation, but one of its most significant moments began four decades ago. Under the leadership of the Communist Party of China (CPC), the country undertook a process of Reform and Opening that revitalized its economy and was able to achieve strong economic growth for the welfare of citizens.

Under the application of this policy, advocated by Deng Xiaoping, China, although with enormous challenges ahead, has achieved great successes in the field of national economy and social development.

Especially for developing countries, the process of reform and opening up is an important legacy and model. Its main value is that China showed the world that it is possible, in a few years, to get out of poverty and underdevelopment, provided that smart policies are applied based on a consistent planning and with a long-term perspective.

\section{Method}

This research focuses on the study and analysis of the growth of the republic of China in the last century through the policies implemented by its leaders and especially the communist party.

This is a current bibliographical review of texts, documents and reports available on the web considering that legacy of globalization allows us to access to a more and better information through 
Gema I. Sornoza-Parrales; Gema M. Conforme-Cedeno; Viviana del Rocío Saltos-Buri; Laura C. Merchán-Nieto; Laura P. Muñíz-Jaime; José A. Franco-Yoza

technological tools. The search engine has been academic tools on the web with specifically address files with validity and recognition.

\section{Results}

Xi Jinping has been consecrated as China's most powerful leader since Mao Zedong after a new body of political thought carrying his name was added to the Communist party's constitution (Phillips, 2017). When Xi Jinping took the lead of the Communist Party of China (CPC) at the $18^{\text {th }}$ Party Congress in 2012, he mentioned his plan of taking the People's Republic of China to a new stage of development (Tsang \& Men, China in the Xi JinPing era, 2015). His agenda, enhancing the role China would play in the world by making the Chinese nation great again, address the grievances of the people and root out corruption. Xi taking the lead in 2012 meant a new period in the era of post-Mao reforms.

After five years in power, Xi managed to be addressed as one of China's core leader ${ }^{l}$, which assures a significant strengthening of his position; since he assumed office, he has rapidly consolidated power. The core leader title is a name he shares with Mao Zedong, who in 1949 founded the People's Republic of China, marking the end of a century of humiliation at the hands of foreign aggressors; and Deng Xiaoping, who put forward the reform and opening-up policy, then paved the way for the nation to become rich. But even though the three of them has had significant importance in Chinese contemporary history, they are three very different men moved by their own goals and visions, who emerged in different times and that had to deal with completely different circumstances.

\footnotetext{
${ }^{1}$ In modern Chinese politics, a leadership core (Chinese: 领旈 recognized as central to the leadership of the Communist Party of China. Four individuals so far have been given this designation: Mao Zedong, Deng Xiaoping, Jiang Zemin, and Xi Jinping.
} 
The objective in this papers is to examine the contrasting nature of these individuals and the circumstances that surrounded their period of leadership, historical context, how they achieved power and also recognize the link they share among the political Chinese system.

\section{Mao Zedong the Great Helmsman}

“Mao Zedong: peasant, revolutionary, philosopher-king. Mao’s life had been deeply paradoxical and self-contradictory. His millenarian vision of a world without egotism and greed, without mandarins, landlords, or bureaucrats, had inspired legendary feats of revolutionary heroism and endurance. Yet the very radicalism of Mao's vision, and the draconian means used to implement it, had visited great suffering upon the Chinese people" (Baum, 1994).

Mao Zedong was the founder member of the Communist Party of China and is considered to be the father of Communist China due to his fundamental involvement in China's recent history. Mao was both a visionary and a revolutionary (Teiwes, 2001) and even though he launched and was responsible for some destructive initiatives he stills remain popular in China.

Mao was a peasant from Hunan province and became the leader of the CCP during 1921. In 1918 while he was working at Beijing University as a librarian assistant, he heard about the successful Russian Revolution, which established the Soviet Union. It was in the context of the reading groups that Mao first became acquainted with Marxism as an analytical method, revolutionary strategy, and critique of the capitalist-imperialist world (Karl, 2010). Inspired by the success of Lenin in achieving the revolution in Russia, Mao believed that in order to create a revolutionary elite in Asia, it was important to concentrate on the countryside rather than the towns to lead a social revolution, as the Marxist revolutionary theory calls. 
Gema I. Sornoza-Parrales; Gema M. Conforme-Cedeno; Viviana del Rocío Saltos-Buri; Laura C. Merchán-Nieto; Laura P. Muñíz-Jaime; José A. Franco-Yoza

He emerged while China was going through a hard period of crisis. China in the 20's was ruled by militarist warlords in the inland areas and by Western and Japanese powers in coastal cities. There was not unified or central China state. Mao was a key role in organizing the alliance between the Nationalists and the Communists that overcame the warlords between 1924 and 1927. After the creation of the Peoples Republic of China in 1949, Mao served as Chairman from 1949 to 1959 and led the Communist Party from 1953 until his death. He was responsible for many of the political initiatives that transformed the face of China, considered a visionary with large goals linked to pragmatic realism. Mao was a leader that showed different perspectives along his many years of power. There was the revolutionary Mao which ideal was to create a united China that stood up for itself against the foreign powers that constantly were attacking it, by developing strategies for the CCP to win power. On the other hand, there is the Mao that repeatedly failed in his attempt of creating a new socialist China, episodes like the Great Leap Forward ${ }^{2}$ or the Cultural Revolution ${ }^{3}$, which were characterized by execution and imprisonment show us another side of the leader.

\section{Deng Xiaoping, the reformer}

In the past, we only stressed expansion of the productive forces under socialism, without mentioning the need to liberate them through reform. That conception was incomplete. Both the liberation and the expansion of the productive forces are essential.

\footnotetext{
${ }^{2}$ The Great Leap Forward was an economic and social campaign by the Communist Party of China (CPC) from 1958 to 1962. The campaign was led by Chairman Mao Zedong and aimed to rapidly transform the country from an agrarian economy into a socialist society through rapid industrialization and collectivization. It is widely regarded by historians that The Great Leap resulted in tens of millions of deaths. A lower-end estimate is 18 million, while extensive research by Yu Xiguang suggests the death toll from the movement is closer to 55 million.

${ }^{3}$ The Cultural Revolution was a chaotic mass movement in the People's Republic of China. Mao Zedong launched it in 1966, claiming that elitists were undermining the government and Chinese society. In fact, the Cultural Revolution crippled the economy, ruined millions of lives and thrust China into 10 years of turmoil, bloodshed, hunger, and stagnation.
} 
In upholding the line, principles, and policies formulated since the Third Plenary Session of the Eleventh Central Committee of the CPC, it is essential to adhere to the principle of "one central task and two basic points". If we did not adhere to socialism, implement the policies of reform and opening to the outside world, develop the economy and raise living standards, we would find ourselves in a blind alley. We should adhere to the basic line for a hundred years, with no vacillation. That is the only way to win the trust and support of the people. Anyone who attempted to change the line, principles, and policies adopted since the Third Plenary Session of the Eleventh Central Committee would not be countenanced by the people; he would be toppled. I have said this several times. Had it not been for the achievements of the reform and the open policy, we could not have weathered June 4th. And if we had failed that test, there would have been chaos and civil war. The "cultural revolution" was a civil war. Why was it that our country could remain stable after the June $4 t^{4}$ Incident? It was precisely because we had carried out the reform and the open policy, which have promoted economic growth and raised living standards. The army and the government should, therefore, safeguard the socialist system and these policies.

\section{Deng Xiaoping 5}

Throughout the initial decade of post-Mao reform, China's new leaders repeatedly tempered their desire for modernization and change with a deep concern for maintaining political order and discipline.

In Deng's mind, as for so many of the "second generation"6 the link of Mao's leadership to the CCP's success was unbreakable. But even Deng was acutely aware that China was in a

\footnotetext{
${ }^{4}$ In 1989, after several weeks of demonstrations, Chinese troops entered Tiananmen Square on June 4 and fired on civilians.

${ }^{5}$ Extract from "Central Document Number 2, Chinese Communist Party Central Committee Circular on Transmitting and Studying Comrade Deng Xiaoping's Important Remarks"
} 
Gema I. Sornoza-Parrales; Gema M. Conforme-Cedeno; Viviana del Rocío Saltos-Buri; Laura C. Merchán-Nieto; Laura P. Muñíz-Jaime; José A. Franco-Yoza

disastrous state. At the beginning of the previous decade, during the Great Leap Forward, more than thirty million people had died. The country was still reeling from the Cultural Revolution in which young people had been mobilized to attack high-level officials and, with Mao's support, push them aside as the country of almost one billion people was plunged into chaos. The average per capita income of Chinese peasants, who made up 80 percent of the population, was then only US\$40 per year. The amount of grain produced per person had fallen below what it had been in 1957. (Vogel, 2011).

Deng Xiaoping was conscious of the need of China for reforms, and he did it, he is responsible for opening the country to science, technology and new ideas from different places of the world. For him, the only organization that would be able to succeed in the rebuilding of the Nation was the Communist Party, but he knew that even the Party would have to change its goals and methods. Under his leadership, the government extricated itself from a legacy of massive economic problems and began a sustained program of economic reform (Naughton, 1993). Those reforms initiated a period of rapid economic growth, and take the country out of isolation to take it into the modern world economy.

Deng was a man with presence, more than one observer commented that it was as if the electricity in the room flowed to him. He had the concentrated intensity of someone determined to resolve important matters (Karl, 2010). In contrast to the later Mao's increasingly visionary pursuit of hard-to-define, indeed incoherent goals, Deng was clearly a results-oriented, pragmatic politician seeking wealth and power for China.

\footnotetext{
${ }^{6}$ Eras of leadership in the People's Republic are still distinguished by the names of the most powerful men of their respective times: Mao Zedong, Deng Xiaoping, Jiang Zemin, Hu Jintao and now Xi Jinping.
} 
He knew that Mao's power relied on the obedience his subordinates showed towards him, and he was aware he could not command the reflexive obedience of the late Chairman, where everyone unhesitatingly obeyed his words. But he was also aware of the negative consequences of that kind of leadership, which, after Mao's death his most deeply cherished goals were being dismantled within months of his death precisely because they had been imposed (Teiwes, 2001).

Political circumstances where different for both leaders, with Mao the crucial disruptive conflicts were brought about by the Chairman himself. Mao's unsustainable initiatives, tendency to turn policy questions into matters of political line, and scapegoating of colleagues for failures where he bore the main responsibility resulted in extensive purges during the Cultural Revolution (Teiwes, 2001). In contrast, the key divisions under Deng were consequences of the problematics of the reform program itself which, at least in broad outline, had consensus support. Deng problems where more focused on either the reforms were sustainable or too risky, or ideological issues such as where to draw the line between plan and market. He also stated that opening and reform required experimentation and mistakes were impossible to avoid, but emphasized his ideas of identifying problems, solve them and move forward. He didn't pay special attention to defining his reforms as capitalism or socialism but in improving people's living standards.

\section{Xi Jinping, the Chinese Dream}

"The decision made by Deng Xiaoping on the reform and open door policy is correct, and we will continue to walk down this correct road"

Xi Jinping (2012)

The Xi Jinping decade of leadership started in 2012, and according to his goals, he is determined to lead China towards national rejuvenation while facing the challenge of sustainable 
Gema I. Sornoza-Parrales; Gema M. Conforme-Cedeno; Viviana del Rocío Saltos-Buri; Laura C. Merchán-Nieto; Laura P. Muñíz-Jaime; José A. Franco-Yoza

growth (Tsang \& Men, China in the Xi JinPing era, 2015). Xi has fought harder than his predecessors against corruption and in favor of greater economic and security alliances. (Forbes, 2016). His ambition prevails in the concept of the Chinese Dream, which, is about Chinese prosperity, collective effort, socialism, and national glory; more precisely turn the country into a moderately prosperous society; going from being a regional power to a superpower and a leading global power (Tsang \& Men, China in the Xi JinPing era, 2015).

Xi Jinping had created a new thought on Socialism with Chinese characteristics, which represented the biggest highlight of the 19h National Congress of the Communist Party of China and represented the latest achievement in adapting Marxism to the Chinese context. The Thought on Socialism with Chinese Characteristics for a New Era builds on and further enriches MarxismLeninism, Mao Zedong Thought, Deng Xiaoping Theory, and the Scientific Outlook on Development. This represents a new era for China since the Communist Party is writing a new chapter of 21 st century Marxism with a broader vision to achieve the goals that were set at the milestone congress ${ }^{7}$.

Xi's thought makes eight fundamental issues clear, including the overarching objectives for upholding and developing socialism with Chinese characteristics in the new era, as well as the direction, model, and driving force of development, and the strategic steps, external conditions and political guarantees.

From being the youthful head of an impoverished village in northwest China via Party chief in the nation's advanced eastern regions to leader of the nation, Xi has shown deep understanding of state governance, evident in economic and social reform, foreign affairs and military

\footnotetext{
${ }^{7}$ 19th National Congress of the Communist Party of China (CPC)
} 
transformationFuente especificada no válida.. In regards to economic development Xi has led China to achieve outstanding growth in times when other major economies are facing problems. China now contributes to over 30 percent of world economic growth. Xi emphasizes the abandonment of what is no longer relevant as a way of revitalizing and renewing the country in order to build a rich, socialist-democratic, powerful, civil and harmonious country and at the same time improves the country's relations with other powerful nations. From the time he took over the leadership of the CPC, he immediately put his own stamp on the Party and the country and pushed hard for changes. His chosen approach was to deepen reform-not to change the course but to press on way beyond what had previously been attempted in order to revitalize the reforms started under Deng Xiaoping (Tsang \& Men, China in the Xi JinPing era, 2015).

All his ideas are put together under the idea of building on socialism with Chinese characteristics by reinforcing the system, since he believes that the existing political system is effective enough to accomplish the goals he has set for China; the socialism with Chinese characteristics systems relies on the analytical framework of "consultative Leninism", which according to many authors is the political system that took shape in China after the death of Deng Xiaoping. And was inherited by Xi when he took the power, the system has shown to be resilient but it must be constantly adapted in order to sustain.

Consultative Leninism has five defining characteristics:

1. An obsessive focus upon staying in power, which means The Communist Party is first and threats to its political supremacy should be eliminated.

2. A focus on governance reform designed to pre-empt public demands for democratization. 
Gema I. Sornoza-Parrales; Gema M. Conforme-Cedeno; Viviana del Rocío Saltos-Buri; Laura C. Merchán-Nieto; Laura P. Muñíz-Jaime; José A. Franco-Yoza

3. Sustained efforts to enhance the Party's capacity to elicit, respond to and direct changing public opinion;

4. Pragmatism in economic and financial management and commitment to sustained growth.

5. The promotion of nationalism, integrating a sense of national pride, stressing the greatness of China's history and culture; in place of Communism. (Tsang, Consultative Leninist: China's new political framework, 2009).

As mentioned before, for $\mathrm{Xi}$ the most important instrument to deliver the Chinese Dream is the Communist Party, using it as an instrument of control and governance; he also rejects the Western or liberal democracy as a model for China as he maintains the belief that the Party shouldn't by any means lose its power.

President $\mathrm{Xi}$ has been categorized as a strong and competent leader and his success rest on strategic planning and central decision making.

\section{Conclusion, the three Core Leaders of China}

Mao Zedong and Deng Xiaoping came to power at times of economic and political crisis, and even though Xi inherited a country that was in the path of economic success, he also had to face political problems like corruption inside the Party which was leading to loss of credibility and social unrest among the public.

Mao the revolutionary, was responsible for founding the Communist rule and unifying the nation. Deng, on the other hand, was responsible for the reforms that turned China into a capitalist country but he gave no room to liberal democracy. It could be said that these two leaders are the 
ones who set the path to China's rise as a superpower. $\mathrm{Xi}$, on the other hand, is responsible for making China stronger, propelling the country to a "new era".

Mao, Deng, and $\mathrm{Xi}$ also differed in their leadership style, as Mao went from being a pragmatic visionary who wanted to build an orthodox Stalinist socialism into a paranoid ideologue who was also responsible for chaotic movements that even though didn't destroy the underlying political structure it did disrupt it (Teiwes, 2001). Deng will always be remembered for being the political boss of the reform era, he was a decisive leader who provided the strength for the reforms to move forward and played a central role in the post-Mao restoration. Now President $\mathrm{Xi}$ is the one who is in charge of the rejuvenation of China drawing inspiration from the glories of China's imperial past and the ideals of its socialist present to promote political unity at home and influence abroad (Economy, 2014); his approach has been different to the communist tradition of collective leadership but instead he established himself as the paramount leader within a tightly centralized political system.

Even when the three leaders show different kinds of governance, there is something all of them agree on and is the idea that China is a special nation which doesn't need the intervention of western political theories but instead they believe in the adaptation of socialism to the Chinese context. What holds the future for China still remains uncertain but one thing is sure, President $\mathrm{Xi}$ is determined to make China a top powerful country in the international arena.

\section{Bibliografía}

Baum, R. (1994). Burying Mao: Chinese Politics in the Age of Deng Xiaoping. Princeton University Press.

Economy, E. C. (2014). Xi Jinping Tightens His Grip. Hein Online.

Forbes. (2016). Forbes. Obtenido de https://www.forbes.com/profile/xi-jinping/ 
Gema I. Sornoza-Parrales; Gema M. Conforme-Cedeno; Viviana del Rocío Saltos-Buri; Laura C. Merchán-Nieto; Laura P. Muñíz-Jaime; José A. Franco-Yoza

Karl, R. E. (2010). Mao Zedong And China in the Twentieth-Century world. Durham and London.

Naughton, B. (1993). Deng Xiaoping: The Economist. The China Quarterly.

Phillips, T. (24 de october de 2017). Xi Jinping becomes most powerful leader since Mao with China's change to constitution. Beijing.

Teiwes, D. (2001). Politics at the "Core": The Politicla Circustamces of Mao Zedong, Deng Xiaoping and Jiang Zemin. China Information.

Tsang, S. (2009). Consultative Leninist: China's new political framework. Taylor \& Francis.

Tsang, S., \& Men, H. (2015). China in the Xi JinPing era. China Economics Publishers.

Vogel, E. (2011). Deng Xiaoping and the transformation of China. THE BELKNAP PRESS OF HARVARD UNIVERSITY PRESS.

World Bank. (2012). Obtenido de http://www.worldbank.org/en/news/speech/2017/12/07/fromlocal-to-global-china-role-global-poverty-reduction-future-of-development 